FROM THE ARCHIVES

Editor Alois Pichler

\title{
Chadbourne Gilpatric and Ludwig Wittgenstein: A Fateful Meeting
}

\author{
Stephen Leach \\ s.d.leach@keele.ac.uk
}

\section{Abstract}

On January 111951 Chadbourne Gilpatric met with Wittgenstein to offer him, on behalf of the Rockefeller Foundation, funding for any forthcoming publications. Wittgenstein politely declined the offer as he did not believe his health would permit him to bring any projects to completion. The meeting is referred to in a letter from Wittgenstein to Norman Malcolm and is also recalled by O.K. Bouwsma. Bouwsma learned of it from conversations with Wittgenstein and Gilpatric. However, it is also recounted in Gilpatric's diary. Gilpatric's account comprises the fullest account of the meeting. It has remained unedited, until now, and is here transcribed for the first time. Five years later on February 11956 Gilpatric submitted a report, entitled 'Logician and Mystic', to the Rockefeller Foundation This report adds detail to his original account and summarises the Rockefeller's financial support of the posthumous publication of Wittgenstein's work. It also sketches Gilpatric's view of Wittgenstein's work. 


\section{Chadbourne Gilpatric (1914-1989)}

Chadbourne Gilpatric studied philosophy at Harvard before going to Oxford as a Rhodes Scholar in 1938. From January 1939 he attended lectures on the philosophy of art by R.G. Collingwood. ${ }^{1}$

In the autumn of 1939 Gilpatric returned to America and became a fellow in philosophy at Princeton. When the United States entered the war, "he served first on the Board of Economic Warfare, and then with the U.S. Army in the Office of Strategic Services. From 1947 to 1949 he was the Deputy Chief of Operations for the Central Intelligence Agency." 2 He took up his post at the Rockefeller Foundation as Assistant Director for the Humanities in 1949. We are fortunate in that The Rockefeller Foundation encouraged all of its officers to keep diaries. We are also fortunate in that Gilpatric's diaries are particularly expansive. They run from 1949 to 1964 and contain vivid thumbnail sketches of a number of philosophers, including, to name but a few, Ernest Nagel, Max Black, D.T. Suzuki, Hannah Arendt and Isaiah Berlin.

In Part I of this article I give Gilpatric's full account of his meeting with Wittgenstein, including also supplementary material from Wittgenstein's correspondence and the memoirs of O.K. Bouwsma.

Part II comprises a full (linear) transcription of 'Logician and Mystic' (dated February 1 1956). This document consists not only of a second account of Gilpatric's meeting with Wittgenstein but also an account of the activities of G.E.M. Anscombe and her fellow executors; and Gilpatric's own assessment of Wittgenstein. It is clear that the posthumous publication of Wittgenstein's papers had his wholehearted support.

Finally, Part III notes an elliptical reference in 'On Certainty' to the meeting with Gilpatric.

\footnotetext{
${ }^{1}$ In the summer of 1939 Gilpatric captained a yacht on a voyage to the Aegean. Collingwood accepted his invitation to join the crew as first mate and his record of the voyage was published as The First Mate's Log (1940).

2 https://rockfound.rockarch.org/biographical/Lasset publisher/6ygcKECNI1nb/content/chadbourne-gilpatric?inheritRedirect=false
} 


\section{First Contact}

In the winter of 1949-50 Wittgenstein was in poor health and short of money. With this in mind, and on his own initiative, his friend Norman Malcolm asked Gilpatric about the possibility of offering him a research grant.

When Wittgenstein learned of Malcolm's action, he was grateful; but he protested - 17 February 1950 - that he did not deserve any grant.

The thought of being able to live where I like, of not having to be a burden or a nuisance to others, of doing philosophy when my nature inclines me to do it is, of course pleasant for me, as it would be for anyone else who wants to do philosophy. But I would not accept money from the Rockefeller Foundation unless the directors knew the complete truth about me. The truth is this.

a) I have not been able to do any sustained good work since the beginning of March 1949. b) Even before that date I could not work well for more than 6 or 7 months a year. c) As I'm getting older my thoughts become markedly less forceful \& crystallise more rarely \& I get tired very much more easily. d) My health is in a somewhat labile state owing to a slight anaemia which inclines me to catch infections. This further diminishes the chance of my doing really good work. e) Though it's impossible for me to make any definite predictions, it seems to me likely that my mind will never again work as vigorously as it did, say, 14 months ago. f) I cannot promise to publish anything in my lifetime.

I believe that as long as I live \& as often as the state of my mind permits it I will think about philosophical problems \& try to write about them. I also believe that much of what I wrote in the past 15 or 20 years may be of interest to people when it's published. But it is, nevertheless, perfectly possible that all that I'm going to produce will be flat, uninspired $\&$ uninteresting. There are many examples of people who did excellent work when they were young, \& very dull work indeed when they got old.

I think this is all I can say about it. I believe you should show this letter to the director you approached about me. It is obviously impossible to accept a grant under false pretences, \& you may unintentionally have presented my case in too rosy a light. (WC: 422) 
It is not known whether Malcolm ever did show Wittgenstein's letter to Gilpatric. But after hearing no more of the matter Wittgenstein believed that nothing would come of it. On the 30 July he told Malcolm:

The Rockefeller people didn't write to me, and I don't see that they had any reason; I never wrote to them. Nor could I ever see why they should give me a grant - though it would have been nice if they had done. (WC: 426)

However, Gilpatric was determined to offer Wittgenstein whatever support he could for he was already, independently, fully convinced of Wittgenstein's genius. Consequently Gilpatric, en route to India, called unannounced on Wittgenstein in Oxford in January 1951. He flew from New York to London on 7-8 January, and flew on to India via Turkey on 13 January. His meeting with Wittgenstein took place on Thursday 11 January 1951 and is recorded in a letter written the next day, from Wittgenstein to Malcolm.

Yesterday a Mr Gilpatrick [sic; SL] ${ }^{3}$ from the Rockefeller Foundation visited me. I told him what I wrote to you some months ago, i.e. that in my present state of health \& intellectual dullness I couldn't accept a grant; but I said that if, against all probability \& hope, I should one day find that I could again do worthwhile work in philosophy, I'd write to him. And so we parted on friendly terms. (WC: 432)

The meeting is also recounted in the memoirs of O.K. Bouwsma. Bouwsma recalled seeing Gilpatric in the Mitre in Oxford, where Gilpatric was staying, on the evening of 11 January.

This evening I saw Chadbourne Gilpatrick [sic; SL] [director of the Rockefeller Foundation] in the Mitre. He'd been to see W. this afternoon to offer money. W. was quite agreeable and apparently agreed to let them know if he should again be in condition to work. When Gilpatrick [sic; SL] suggested that the money be used to print any papers that he might have - the world needed them badly - W. said: 'But see, I write one sentence, and I write another - just the opposite. And which shall stand?'

3 “[...; SL]" contains my comments and additions. 
Again he said something about the rot people publish, going on writing after they've stopped thinking. They don't know when to quit. Russell! (Bouwsma 1986: 73)

Then, on Saturday, 13 January, Bouwsma heard about the meeting from Wittgenstein.

He said Gilpatrick [sic; SL] had been to see him. At first Gilpatrick [sic; SL] began talking about language and philosophy - the patter. W. cut that off short. And then he talked sense. W. told him that if, as was unlikely, he would be able to write again, he would write to him. (ibid.: 75)

Gilpatric's own account of the meeting, previously untranscribed, is reproduced in linear transcription below.

January 11, 1951

Ludwig Wittgenstein, author of "Tractatus Logico-Philosophicus" in 1922, has probably had the greatest individual influence among living or recent philosophers on orientation and analytic methods in that field since 1920. In Anglo-American thought at least. His influence has been personally transmitted, and its effects are to be found among many of the ablest young men. Unquestionably a genius, he has the oddities of genius: he is completely intolerant of pretension and insincerity, enjoys solitariness, and takes unusual measures to keep himself out of the reach of all those who are not close friends or serious thinkers. After retirement from his Professorship at Cambridge, he went into virtual hiding at Oxford where he has tried, when health permitted, to clear up the more difficult puzzles about use of sophisticated language, especially mathematics. He has been writing for himself along these lines for twenty years, and is known to have crystallized his reflections on paper - in chunks. Norman Malcolm of Cornell, Wittgenstein's closest American friend, had suggested to CG that Wittgenstein's financial needs are acute and that help might hasten the completion of his work. Accordingly, CG began the search for Wittgenstein in Oxford - having to use the techniques of a private eye. He lives with Elisabeth Anscom [sic; SL] who could be located only by her married name, Mrs Geach (which she never uses for social purposes). She lives at 27 St John Street in a small, untidy attic room. With a huge patch covering one eye and soiled blue trousers enclosing fat thighs, she reluctantly admitted me. Malcolm's name was the password to see her 
room, where the literature of an Existentialist-become-Catholic was scattered about. She explained that Wittgenstein is sick and remains in bed except for a few hours at the end of the day. She finally went into his room and obtained consent for me to see him at six in the evening.

To jump ahead, CG returned at six when Wittgenstein was up and dressed in shabby clothes over his pajamas. Wittgenstein is in his late sixties [he was 61 at the time of this interview; SL] and is obviously a very sick man. In appearance and manner of expression, he makes a powerful impression. His face has an ascetic leanness, and his skin is remarkably fair with a kind of beauty most women would envy. His eyes dominate and control your attention. He speaks with great simplicity and compelling earnestness. At once you sense his intellectual power and moral force. He went on to describe how his thinking powers had failed and how for months he had felt no spark, no quick, fresh flow of ideas. He would say nothing about recent lines of thought because, as he said, he was bitterly dissatisfied with many attempts at formulation in the last two years. In response to a direct question about likelihood of finishing his work in book form - in progress for twenty years - he said he was no longer able to work and expected he never could again. He was firm in saying that he would accept no help from RF [the Rockefeller Foundation; SL] or any other agency because he did not deserve it. He promised to write CG whenever he found himself waking up and capable of resuming philosophy. In passing he spoke with scorn of philosophers who fail to admit their limitations and write rot. I think he had Bertrand Russell and other voluble British philosophers in mind. Asked if he would publish any of his part writings [i.e. unfinished writings; SL], Wittgenstein said that he had a large number of manuscripts which showed the traces of constant refinement in expression. In many cases he had tried to express the same point in several different ways. Now he does not feel competent to choose which among alternatives is the better formulation. Therefore he will not edit or release anything he has written until he feels himself intellectually fit. If this happens, he will notify CG; if it does not, Elisabeth Anscom [sic; SL] will be his philosophical executor. This may prove to be an unfortunate provision. ${ }^{4}$

\footnotetext{
${ }^{4}$ Rockefeller Archive Center, RG 12, F-L (FA 392), Box 164. https://storage.rockarch.org/74dc16eb-75c5-4a5f-b2f7-8c609ab714e2Gilpatric 1951.pdf
} 
Gilpatric's initial unease at the appointment of Anscombe as executor may have been based on no more than her initially uncooperative manner and her untidy room. But his regard for the value of publishing Wittgenstein's work was never in doubt.

The next morning Isaiah Berlin, with whom he had had lunch the previous day, quizzed him about the meeting; but Gilpatric was not in a mood to indulge him.

Part of breakfast was taken at the Mitre and the rest with Berlin in his rooms at New College. He was curious about Wittgenstein, but knowing Berlin's propensities to gossip and extrapolate little was said by CG on the subject.

He reserved his full account of the meeting for his diary.

\section{Logician and Mystic}

In a will drawn up on 29 January Wittgenstein named the administrators of his literary estate as G.E.M. Anscombe, G.H. von Wright and Rush Rhees. He died exactly three months later at the age of sixty-two.

The story of the collaborative efforts of Anscombe, Rhees and von Wright to edit and publish Wittgenstein's manuscripts, over the nine months immediately following Wittgenstein's death, has been told in Erbacher and Krebs (2015). That story is complemented and extended by a report, dated February 1 1956, in the archives of the Rockefeller Foundation entitled 'Logician and Mystic'.

The report quotes Gilpatric's conversation with Norman Malcolm, in which the subject of financial support was first broached, as well as Gilpatric's own diary. It also adds some detail to Gilpatric's original account of the meeting with Wittgenstein. On these grounds it is reasonable to assume that the author is Gilpatric, albeit sometimes making use of the diaries of his fellow officer Edward F. D'Arms.

Furthermore, the report relates details of the Foundation's support of G.E.M. Anscombe's editorial work and gives a succinct

${ }^{5}$ Rockefeller Archive Center. RG 1.2, Series 401R, Box 41, Folder 373. 
and well-written summary of Wittgenstein's life and work. Gilpatric again makes clear that the publication of Wittgenstein's papers has his wholehearted support.

'Logician and Mystic' is transcribed below in full.

Grants from the Foundation:

$\$ 16,200$ to Somerville College, Oxford

February 1, 1956 [written in hand; SL]

\section{"LOGICIAN AND MYSTIC"}

Our story begins in Ithaca, on the Cornell University campus. Chadbourne Gilpatric, assistant director for the Humanities, was there in 1949 visiting Foundation-supported projects, and in the course of his calls he saw Norman Malcolm, professor of philosophy. Professor Malcolm, reviewing trends and developments in philosophy, spoke of the continuing influence of Ludwig Wittgenstein, the Austrian-born philosopher and mathematician who had retired from his professorship at Cambridge University two years before. "Wittgenstein is now living in seclusion in Oxford, ill and in extremely frugal and self-denying circumstances, refusing to see visitors or to accept charity," said Malcolm, "but he might accept the sort of impersonal aid The Rockefeller Foundation would be able to offer. Indeed, in my opinion," the Cornell professor went on, "the Foundation could contribute an important service to scholarship and to society by making it possible for Wittgenstein to publish his writings before he dies." 6

Gilpatric knew of Wittgenstein. Though unknown to the general public, he was widely hailed among scholars as one of the most original and penetrating minds of our time, and at least two schools of philosophy - the logical positivists of the Vienna Circle and the analytic or linguistic school which was associated with Cambridge - had acknowledged their

\footnotetext{
${ }^{6}$ Malcolm dates his meeting with Gilpatric to the spring of 1950 (Malcolm 1984: 78). Gilpatric's diaries do not mention a meeting with Malcolm but it is evident from his diaries that he was in Ithaca on 5 and 6 December 1949. However, Wittgenstein only moved to Oxford on 25 April 1950 (Monk 1990: 567). Gilpatric may be conflating two separate meetings with Malcolm. At any rate, we know that Malcolm and Gilpatric met before February 17 1950, for this is when Wittgenstein refers to their conversation in a letter to Malcolm.
} 
indebtedness to Wittgenstein's germinal ideas. His avoidance of publicity, his inaccessibility to any but a few intimate disciples, his progressive rethinking and un-hesitating revision of his earlier views, and his fearless independence of sectarianism of every kind had fostered the growth of legends, and Wittgenstein was variously pictured as both logician and mystic. It was known that he was continually writing and rewriting - so his few intimates reported - and yet, apart from a philosophical treatise published in 1922 under the formidable title Tractatus LogicoPhilosophicus, and a single magazine article since, not a word of his had appeared in print. The Foundation officer therefore listened sympathetically to the Cornell professor's suggestion. The possibility of helping a great thinker to formulate and make public a definitive statement of his philosophy was at least worth exploring, and Gilpatric resolved to look the man up on his next trip to England. More than a year passed, but January of 1951 found him at last in London, and soon after getting settled he took the train for Oxford.

\section{St. John Street}

Malcolm had remarked that it would be fruitless to write for an appointment. He suggested that the best way to reach Wittgenstein would be through his student, Elizabeth Anscombe, a lecturer on the Oxford staff. But the university directory listed no Anscombe and Gilpatric inquired among his acquaintances in the philosophy faculty. None was able to direct him, and one don, on hearing that the real object of his search was Wittgenstein, threw up his hands. "You'll never get to Wittgenstein," he declared. "He is a complete recluse; never shows himself; nobody knows where he lives." But Gilpatric kept on inquiring, and eventually discovered that Elizabeth Anscombe was the wife of a Cambridge lecturer named John Geach [Peter Geach; SL]. She was listed in the directory only under her married name and as living at 27 St. John Street.

When he rang the bell at that address, the door was opened by a woman in faded blue trousers and a frowsy jacket, who wore a black patch over her right eye. With her other eye she surveyed her visitor, grudgingly admitting that she was Elizabeth Anscombe. The name of Professor Malcolm proved to be the password. When Gilpatric mentioned that the Cornell professor had asked him to call and inquire about Professor Wittgenstein, she led the way upstairs to an untidy attic room littered with books and papers. Wittgenstein was sick, she said; he stayed in bed all day, except for a brief period in the late afternoon; and he saw nobody, 
Gilpatric urged that Malcolm was very anxious that he meet his friend, that he would be glad to call at any time and place, and that in any event he would make the visit brief. On this assurance, Miss Anscombe said she would transmit the request.

Shortly after noon that same day, a messenger brought Gilpatric an invitation to call at 27 St. John Street at six o'clock. Arriving on the stroke of the hour he was again admitted by Miss Anscombe (now more conventionally garbed), again climbed the stairs to the attic, and there in an adjoining room was Wittgenstein.

The 62-year-old philosopher [actually still 61; SL] presented a striking appearance in the meager setting of his small room, furnished only with a bed, a table, a chair, and a small bookcase. He was clad in a shabby suit of clothes, apparently pulled on over pajamas, his head crowned with a thatch of unruly white hair. "His smooth face had an ascetic leanness," recalls Gilpatric, "and his skin was remarkably fair, with a kind of beauty that most women would envy. His eyes had a searching quality. He spoke with great simplicity and compelling earnestness, in faultless English, conveying an instantaneous impression of intellectual integrity and moral force." 7

When the Foundation officer broached the subject of Wittgenstein's writings; and suggested that it might be possible to provide a grant to enable him to devote his full time and efforts to putting his ideas in form for publication, the philosopher sadly shook his head.

"It's true I have important work to do," he said, "but I can't do it. My mind is dead; for months now I have felt no spark, no quick fresh flow of ideas. I know what it is to think lucidly and straight, and I know that in my present condition straight thinking is impossible. I don't trust my judgment to say which of two alternatives is valid. ${ }^{8}$ It's a terrible situation to be in. Unfortunately, though, there are people who are unwilling to acknowledge their incapacity. For many - and this is true, I am sad to have to say, of some modern English philosophers - it doesn't matter how sick and fumbling their minds have come to be, they continue to write and to talk and the result is pathetic twaddle. I am bitterly dissatisfied with many attempts at formulation that have come to my attention in the last few

\footnotetext{
${ }^{7}$ Gilpatric is here quoting from his 1951 diary.

${ }^{8}$ However, in Gilpatric's diary Wittgenstein is recorded as saying that there are many instances in which he has expressed the same point in different ways and he no longer feels himself competent to judge between them. Presumably, on this point, the diary is the more reliable source.
} 
years, but I wouldn't trust myself to reformulate them - not while I am in a mental fog."

After this outburst - which obviously was aimed at his former friend, Bertrand Russell - he became a little more matter of fact. He had thought of going back to Norway, where he could work in peace and solitude, he said, and it would of course be a great help if an institution like The Rockefeller Foundation were interested enough in what he had to do to provide the wherewithal. He knew of the Foundation in other connections, he said, and had respect for its great disinterestedness and integrity. But, he quickly added, in his present state of intellectual impotence he did not deserve such patronage and could not accept it, "All I can do now is to hope that some day I'll come out of this depression and find that again I can think straight. If that day ever comes," he promised, "I'll write my friend Malcolm and perhaps he'll tell you."

This interview was on January 11 . The next day Gilpatric returned to London and took off for New Delhi on a several-months survey of humanities prospects in India and Pakistan. In May word came that Wittgenstein was dead; he had been taken to Cambridge for medical treatment and had died there of cancer on April 29.

\section{The Wittgenstein Papers}

Before he died Wittgenstein appointed three friends as literary executors: Miss Anscombe, Georg H. von Wright of Cambridge University, and Rush Rhees of Swansea College, Wales. When the executors opened a safe which belonged to the philosopher, they found it filled with manuscripts of many kinds, all in German and written in the special idiom of the Austrian Tyrol. ${ }^{9}$ Despite his long residence in England, Wittgenstein always insisted that he could express his ideas most clearly in this dialect, and he specified that when any of his writings were translated, the original German text must be published in the same volume with the English version.

The most finished of his literary remains was a sizable work which Wittgenstein had entitled Untersuchungen ("Investigations"). He had been working on it intermittently for the last 20 years, and so far as the German version was concerned it was ready for publication. One of the literary executors' first acts was to show this manuscript to the British publishing firm of Blackwell's, which had expressed an interest in Wittgenstein, and

\footnotetext{
${ }^{9}$ This is not correct; Wittgenstein was not writing in the dialect of the Austrian Tyrol, but in standard Austrian German.
} 
they readily agreed to publish it. Miss Anscombe was appointed translator, and she spent some time in the Austrian Tyrol in the summer of 1951 to familiarize herself with the idiom. The book appeared in 1953 under its English title, Philosophical Investigations.

Next to Investigations, the manuscript nearest to completion was Bemerkungen ("Notes") It reflected Wittgenstein's preoccupation with meaning - "everything that can be said can be said clearly" - and consisted of a series of numbered paragraphs. Other papers dealt with the philosophical basis of mathematics, Altogether, the executors estimated, there was systematic material, apart from the purely fragmentary, sufficient to fill six or seven volumes. Each needed editing, and of course it was important to put the material into English. Because of her long association with Wittgenstein and her familiarity with his thinking, the other executors agreed that Miss Anscombe was the most suitable editor and translator, and this appointment was also approved by Somerville College, Oxford, where Miss Anscombe was employed as a research fellow in philosophy.

Since The Rockefeller Foundation had once indicated to Wittgenstein an interest in his writings, Somerville College now raised the question whether the Foundation would be willing to finance the editing and preparation of his papers for publication. In October of 1951 Edward F. D' Arms, associate director for the Humanities, visited Oxford and interviewed Janet Vaughan, principal of Somerville College, along with Miss Anscombe, Professor von Wright, and Herbert Hart, a philosophy don at New College, Oxford. Meanwhile, too, Malcolm of Cornell had added his endorsement to the project. All agreed that early publication was greatly to be desired.

Dr. Vaughan, who was formerly a Rockefeller fellow in medicine and continues medical research in Oxford in addition to running Somerville College, spoke in high terms of Miss Anscombe. Like Dr. Vaughan herself, Miss Anscombe has several children. Her husband's position on the philosophy faculty at Cambridge [actually Birmingham; SL] made it necessary for him to live there, whereas Miss Anscombe's work at Oxford required her to live in its vicinity. Until recently the children stayed in Cambridge with their father and Miss Anscombe went over for weekends. But since Wittgenstein's death, the children have been transferred to the Oxford menage and Dr. Geach comes there for weekends. "Miss Anscombe has unselfishly nursed the ailing Wittgenstein for years and helped him 
with his research and writing," ${ }^{10}$ said Dr. Vaughan, and she voiced the highest esteem for Miss Anscombe as a person, as a fellow of Somerville, as a philosopher, and as a research worker. Both von Wright and Hart confirmed this good opinion. (Later, when Wittgenstein's significance was discussed at an officers' conference in New York, Warren Weaver said that Wittgenstein's contributions to logic might well turn out to be of more importance than those of Bertrand Russell or A.N. Whitehead.)

On the strength of these recommendations, the Foundation in December, 1951 , made a grant in aid of $\$ 5,400$ to Somerville College. Additional grants have since brought the total to $\$ 16,200$ and extended the assistance to 1958. The two accomplishments thus far have been:

1. Publication of Philosophical Investigations, which was edited jointly by Miss Anscombe and Rush Rhees and translated by Miss Anscombe. Most of this work was done before the first grant became effective, and only the final typing and proofreading were financed with Foundation funds.

2. Compilation of Remarks on the Foundation of Mathematics, a treatise distilled from notes comprising about twice as much material as is being published. Work on this book has claimed the major part of Miss Anscombe's time during the last three years; the manuscript is now in type, and publication is expected before spring.

Miss Anscombe is now translating the notebooks from which Wittgenstein wrote his famous Tractatus Logico-Philosophicus of 1922, These are of basic importance for understanding the Tractatus, and the literary executors were unanimous in voting that they be the third publication under the present program. "I expect to have a translation ready for editorial discussion with Professor von Wright and Professor Rhees in April," Miss Anscombe wrote in October. "We propose to get out a volume consisting mainly of these notebooks with the addition of a manuscript that Wittgenstein sent Bertrand Russell before the first World War and dictated to Professor G.E. Moore a little later, and some letters to Russell. All this has to do with the Tractatus. I presume we can hope for publication early in 1957."11

When the notebooks are ready for the printer, Miss Anscombe will begin translating a work dated about 1930, which is complete; after that

\footnotetext{
${ }^{10}$ October 22 1951, quoting from the diary of Edward F. D'Arms. Rockefeller Archive Center. Record Group 1.2, Series 401R, Box 41, Folder 373.

${ }^{11}$ October 18 1955, Anscombe to Gilpatric. Rockefeller Archive Center. Record Group 1.2, Series 401R, Box 41, Folder 373. (Notebooks, 1914-1916 were published in 1961.)
} 
she plans to compile a volume on the philosophy of psychology, a writing in which Wittgenstein was engaged during the period of his Investigations.

"The thought of Philosophical Investigations is quite incomplete without some account of what that method of thinking leads to for logic and mathematical knowledge," explained Miss Anscombe. "The volume that is now in press - the Remarks - fills this gap, Further, the indirect influence of Wittgenstein's later work - through derivative schools such as the Oxford 'linguistic school' - often tends to be a bad one, and one which can in part be counteracted by an increase in understanding of his Tractatus and the connections between that work and his Investigations. In spite of its fame, the Tractatus has never been assimilated, understood, even discussed in the philosophical world. Nevertheless, interest in it is growing. A publication which may aid readers to understand the Tractatus will, we hope, be of value in correcting misinterpretations of it and also of the Investigations. Hence the work immediately in hand."12

\section{The Man and His Philosophy}

The layman - to whom even the name, and much more the philosophy, of Wittgenstein is unfamiliar - may wonder why so much importance is attached to the writings of this unknown. Here is how the Oxford professor Isaiah Berlin characterized the man and his teachings at the end of 1951, in an article for the Britannica Book of the Year:

The more rigid forms of Positivism were still melting both in Britain and the United States into a far more imaginative and sensitive, if not less empirical, instrument - and this appeared to be largely the effect of the oral doctrines of the Austrian philosopher Ludwig Wittgenstein, who died in Cambridge, England, in the course of the year, leaving disciples devoted to his memory and his methods to a degree of which no other philosopher of the day could boast. Wittgenstein had begun as a Logician and the follower of Bertrand Russell, but at the height of his philosophical development altered his views, and practiced a technique whereby more light was thrown on some of the most tormenting problems of modern philosophy than the older and more mechanical methods had succeeded in doing. This new and more flexible method required qualities of imagination and insight, and even a kind of poetical genius,

${ }^{12}$ October 18 1955, Anscombe to Gilpatric. Rockefeller Archive Centre. Record Group 1.2, Series 401R, Box 41, Folder 373. 
which Wittgenstein himself possessed to a degree not shared by even his most gifted disciples. His teaching was the most fruitful contribution to the abstract thought of the day made by any single human being. His influence, powerful enough already, seemed likely to spread further, as a result of the vigorous proselytizing activities of his disciples.

Georg H. von Wright, one of the philosopher's literary executors, has been seeking to authenticate the details of his life, and in doing so is dispelling many of the legends which grew up over the years. Von Wright was a close friend of Wittgenstein's, and succeeded him in the chair of philosophy at Cambridge; although he has since returned to his native Finland and accepted appointment at the University of Helsinki, von Wright has continued to pursue his biographical quest. The first fruit of this appeared last October in the Philosophical Review, under the title, "Ludwig Wittgenstein, a Biographical Sketch," and we are indebted to von Wright's paper for most of the details which follow.

Wittgenstein was born in Vienna on April 26, 1889, the son of an engineer who became a leading figure in the Austrian steel industry and amassed a large fortune. Ludwig, the youngest of three [actually four; SL] brothers and five [actually three; SL] sisters, was educated at home until his fourteenth year, after which he spent three years in school at Linz. Then, having decided to enter engineering, he enrolled in the Technische Hochschule in Berlin-Charlottenburg. After two years there he went to England, and spent the summer of 1908 experimenting with kites at the Upper Atmosphere Station in Derbyshire. In the autumn he registered as a student of engineering at the University of Manchester. His three years at Manchester were largely occupied with research in aeronautics, including studies for the design of a jet-reaction propeller.

"Wittgenstein once mentioned to me that the problems on which he worked during his Manchester years have since become very urgent," von Wright records. "I regret that I was not curious enough to ask him more. I assume that he was thinking of the role which the reaction engine has recently come to play, especially in aeronautics." ${ }^{13}$

Up to now Wittgenstein's education and interest had been focussed on mechanics. Problems encountered in propeller design took him to pure mathematics, and from pure mathematics his curiosity led him to the philosophical basis of mathematics. During this period of seeking he asked someone for advice and was directed to Bertrand Russell's Principles of

\footnotetext{
${ }^{13}$ von Wright 1955: 529.
} 
Mathematics. This book profoundly affected the young engineer, and its references led him to study the works of the German philosopher Gottlob Frege. "The 'new' logic, which in Frege and Russell had two of its most brilliant representatives, became the gateway through which Wittgenstein entered philosophy," relates von Wright, ${ }^{14}$ for sometime in 1911 he decided to abandon engineering and forthwith went to Jena to discuss his plans with Frege. Frege advised him to go to Cambridge and study with Russell, and at the beginning of 1912 the former engineer was admitted to Trinity College and registered in Cambridge University. He was 23 years old.

"Getting to know Wittgenstein was one of the most exciting intellectual adventures of my life," 15 Bertrand Russell later wrote in an article telling of his acquaintance with the young Austrian. Russell was then at the height of his powers. He and A.N. Whitehead had collaborated in writing that milestone in the history of logic, Principia Mathematica, and Wittgenstein came to know not only Russell and Whitehead, but G.E. Moore, John Maynard Keynes, and G.H. Hardy, the mathematician. He visited Norway in the autumn of 1913, and soon decided to give up his studies at Cambridge. His father had died in 1912, leaving him economically independent, and Wittgenstein now built himself a hut in an isolated place on a Norwegian farm and lived there in seclusion until the outbreak of war in 1914, Then he hastened to Vienna and enlisted as a volunteer in the Austrian army.

Wittgenstein served in various military capacities, and was fighting against the Italians on the south front in 1918 when the Austro-Hungarian army collapsed. He became a prisoner of the Italians and was confined for nearly a year in a camp near Monte Cassino. In his rucksack when he was captured was a bulky paper, the manuscript of Tractatus LogicoPhilosophicus, which his captors allowed him to keep. From the prison camp he wrote to Bertrand Russell, and eventually, using John Maynard Keynes as his intermediary, sent the manuscript to Russell.

Apparently it was in the period after he had left Cambridge, and while living in isolation in Norway, that Wittgenstein began to write down the thoughts which later became the Tractatus. The manuscript was still fragmentary when he went to war, but he completed it in August, 1918, when he was in Vienna on leave.

\footnotetext{
${ }^{14}$ von Wright 1955: 530.

${ }^{15}$ Russell 1951: 298.
} 
"The oldest parts of the Tractatus are those dealing with logic," says von Wright. "Later he became engrossed in a new problem. It was the question of the nature of the significant proposition. Wittgenstein told me how the idea of language as a picture of reality occurred to him. He was in a trench on the east front, reading a magazine in which there was a schematic picture depicting the possible sequence of events in an automobile accident. The picture there served as a proposition; that is, as a description of a possible state of affairs. It had this function owing to a correspondence between the parts of the picture and things in reality. It now occurred to Wittgenstein that one might reverse the analogy and say that a proposition serves as a picture, by virtue of a similar correspondence between its parts and the world. The way in which the parts of the proposition are combined - the structure of the proposition - depicts a possible combination of elements in reality, a possible state of affairs." 16

In summary: "Wittgenstein's Tractatus may be called a synthesis of the theory of truth-functions and the idea that language is a picture of reality. Out of this synthesis arises a third main ingredient of the book, its doctrine of that which cannot be said, only shown." ${ }^{17}$ As another has expressed it. "Philosophy is not a science; it cannot yield theories or doctrines. None the less it can be skilful or unskilful, successful or unsuccessful. It is in pursuing the activity itself that we see what we need to see. Rather like learning music or tennis, learning philosophy does not result in our being able to tell what we have learnt; though, as in music and tennis, we can show what we have learnt." ${ }^{18}$

It was largely due to Bertrand Russell's insistence that the Tractatus got published; for, after an argument over Russell's introduction to the book which Wittgenstein found objectionable, he turned his back on the whole undertaking and Russell persuaded Kegan Paul to publish the work. It appeared in 1922 in a German-English parallel text.

Meanwhile, Wittgenstein, having come into his father's fortune, gave it away shortly after his release from the Italian prison camp. Thereafter a great simplicity, at times a great frugality, became characteristic of his life. He became a schoolmaster and from 1920 to 1923 taught in several villages of Austria. Then for a while he served as gardener's assistant at a monastery. After this he turned architect and

\footnotetext{
${ }^{16}$ von Wright 1955: 532-533.

${ }^{17}$ von Wright 1955: 533.

${ }^{18}$ Ryle 1951: 5.
} 
designed and supervised the construction of a mansion in Vienna for one of his sisters.

At last, in 1929, Wittgenstein decided to resume the study of philosophy, and he returned to Cambridge. The university awarded him the Ph.D. degree the following June, he was made a fellow of Trinity College, and he lectured on philosophy from 1930 until the expiration of his fellowship in 1935. Then back to his hut in Norway, and it was during this second period of withdrawal that he began to write Philosophical Investigations.

Wittgenstein returned to Cambridge and in 1939 was appointed to succeed G.E. Moore as professor of philosophy. When the war broke out he was unwilling to watch it from an ivory tower; so he volunteered for medical service, working for a while as a porter at Guy's Hospital and later in a medical laboratory. He gave his last lectures in 1947 and toward the end of that year ceased to be a professor. Seeking seclusion again, he withdrew to Ireland, living for a while in a hut on the Galway coast but finally settling for a hotel room in Dublin, and here he completed the second part of Philosophical Investigations. Ill health overtook him in 1949, after his return to England, but he continued to work intermittently, and von Wright reports that "during his last two months he was not in bed and was apparently in the best of spirits. As late as two days before his death he wrote down thoughts that are equal to the best he ever produced."19

We have mentioned that Wittgenstein repudiated some of his earlier views and developed an entirely new philosophy. This change began in the early 1930's, when he was lecturing at Cambridge. "He abandoned the picture theory of language," says von Wright, "the doctrine that all significant propositions are truth-fictions [sic; SL] of elementary propositions, and the doctrine of the unspeakable." 20 His "new" philosophy is perhaps best presented in the, recently published Philosophical Investigations, and it signalizes a radical departure from the previously existing paths of philosophy.

Indeed, declares von Wright, "Wittgenstein's new philosophy is entirely outside any philosophical tradition and without literary sources of influence, and for this reason it is extremely difficult to understand and to characterize." ${ }^{21}$ As author of the Tractatus he had learned from Russell and Frege and grappled with problems that grew out of theirs, but as author

\footnotetext{
${ }^{19}$ von Wright 1955: 541-542.

${ }^{20}$ von Wright 1955: 538.

${ }^{21}$ von Wright 1955: 539.
} 
of the Investigations Wittgenstein has no ancestors, and grapples with problems that grew out of his own creative thinking. The style in which the Investigations is written has been described as simple and perspicuous. "The form is sometimes that of dialogue, with questions and replies; sometimes, as in the Tractatus, it condenses to aphorisms. There is a striking absence of literary ornamentation, of technical jargon or terminology." 22 Von Wright thinks that one day Wittgenstein will be ranked among the classic writers of German prose.

From this abbreviated account of his multi-dimensioned career, it must be clear that in Wittgenstein many contrasts meet, Von Wright points to the contrast between "his searching, restless personality and the repose and perfection of his work." ${ }^{23}$ Although he asserted that "the riddle does not exist" and that "everything that can be said can be said clearly," Wittgenstein was himself an enigma and much that he spoke and wrote lies deep beneath the surface of language.

"It has been said that he was at once a logician and a mystic," von Wright recalls, and adds that "neither term is appropriate, but each hints at something true. Those who approach Wittgenstein's work will sometimes look for its essence in a rational, matter-of-fact dimension, and sometimes more in a supra-empirical, metaphysical one. In the already existing literature on Wittgenstein there are examples of both conceptions. Such interpretations have little significance. They must appear as falsifications to anyone who tries to understand Wittgenstein in his rich complexity. They are interesting only as showing in how many directions his influence extends. I have sometimes thought that what makes a man's work classic is often just this multiplicity, which invites and at the same time resists our craving for clear understanding." 24

\section{Mr. N. N.}

In his meeting with Gilpatric Wittgenstein made clear that he believed his most productive days were behind him. However, contrary to his own expectations, he experienced an unexpected creative rallying in which, in the final two months of his life, he wrote paragraphs 300-676 of On Certainty (Monk 1990: 577-578).

\footnotetext{
${ }^{22}$ von Wright 1955: 544.

${ }^{23}$ von Wright 1955: 545.

${ }^{24}$ von Wright 1955: 545.
} 
He lost consciousness on 28 April and died on 29 April but on 27 April he was still writing. As von Wright noted: "As late as two days before his death he wrote down thoughts that are equal to the best he ever produced." 25 His writing on that day included the following:

673. Is it not difficult to distinguish between the cases in which I cannot and those in which I can hardly be mistaken? Is it always clear to which kind a case belongs? I believe not.

674. There are, however, certain types of case in which I rightly say I cannot be making a mistake, and Moore has given a few examples of such cases. I can enumerate various typical cases, but not give any common characteristic. (N.N. cannot be mistaken about his having flown from America to England a few days ago. Only if he is mad can he take anything else to be possible.)

675. If someone believes that he has flown from America to England in the last few days, then, I believe, he cannot be making a mistake.

And just the same if someone says that he is at this moment sitting at a table and writing. (OC 1969)

I may be mistaken, but I believe that in these lines it was the memory of the meeting with Gilpatric that provided him with the example he was looking for. (It is hardly surprising that in his last days his thoughts turned to the fate of his manuscripts.)

\section{References}

Bouwsma, O.K., 1986. Wittgenstein. Conversations 1949-1951, eds. J.L. Craft \& R.E. Hustwit. Indianapolis: Hackett.

Erbacher, C. and Krebs, S., 2015. "The First Nine Months of Editing

Wittgenstein: Letters from G.E.M. Anscombe and Rush Rhees to G.H. von Wright". Nordic Wittgenstein Review, 4 (1), 195-231.

Malcolm, N., 1984. Ludwig Wittgenstein: A Memoir. Oxford: Oxford University Press.

Monk, R., 1990. Ludwig Wittgenstein: The Duty of Genius. London: Jonathan Cape.

Russell, B., 1951. "Ludwig Wittgenstein". Mind 60, 297-298.

${ }^{25}$ von Wright 1955: 541-542. 
Ryle, G., 1951. "Ludwig Wittgenstein". Analysis, October 1951, 12 (1), 1-9. Wittgenstein, L., 1969. On Certainty, trans. D. Paul \& G.E.M. Anscombe, eds. G.E.M. Anscombe \& G.H. von Wright. Oxford: Blackwell. [OC 1969] Wittgenstein, L., 2012. Wittgenstein in Cambridge. Letters and Documents $1911-$ 1951, ed. B. McGuinness. Oxford: Wiley-Blackwell.

von Wright, G.H., 1955. "Ludwig Wittgenstein, A Biographical Sketch". The Philosophical Review vol. 64, no.4 (Oct. 1955), 527-545.

\section{Licensing and acknowledgments}

To the extent that it is legally entitled to do so, the Rockefeller Archive Center has granted the author and the Nordic Wittgenstein Review permission to publish materials from the Rockefeller Foundation Archives Record Group 12, Officers' Diaries - Chadbourne Gilpatric, and Record Group 1.2, Series 401 R, Box 41, Folder 373, "Oxford University - Anscombe, Gertrude E.M." Please note that this permission is granted for one-time use only, so that future editions or editions in other languages will require additional permissions. The Rockefeller Foundation maintains intellectual property rights to Rockefeller Foundation-related materials.

The author thanks the section editor Alois Pichler and Bethany J. Antos of the Rockefeller Archive Center in Sleepy Hollow, New York, the discoverer of 'Logician and Mystic'.

\section{Biographical Note}

Stephen Leach is Senior Honorary Fellow at Keele University. He is the co-editor (with James Tartaglia) of Consciousness and the Great Philosophers (Routledge, 2017) and The Meaning of Life and the Great Philosophers (Routledge, 2018). 